and it was soon made apparent that the genus Paradoxides, both here and in North Wales, was confined to a horizon below the great mass of the Lingula flags, which, on the contrary, are characterised by numerous species of Olenus. These lower or Menevian beds are hence regarded by Salter as equivalent to the lowest portion of the Etage C of Barrande.

Beneath these Menevian beds there lies, in apparent conformity, the great Lower Cambrian series, frequently called the bottom or basement rocks by the Government surveyors ; represented in North Wales by the Harlech grits, and in South Wales, near St. David's, by a similar series of green and purple sandstones, considered by Murchison and by others as the equivalent of the Harlech rocks. They were still supposed to be unfossiliferous until, in June 1867 , Salter and Hicks announced the discovery in the red beds of this lower series, at St. David's, of a Lingulella, very like $L$. ferruginea of the Menevian (Geol. Jour. xxiii. 339 ; Siluria, 4th ed. 550). This led to a further examination of these Lower Cambrian beds, which has resulted in the discovery in them of a fauna distinctly primordial in type, and linked by the presence of several identical fossils to the Menevian; but in many respects distinct, and marking a lower fossiliferous horizon than anything known in Bohemia or in Scandinavia.

The first announcement of these important results was made to the British Association at Norwich in I868. Further details were, however, laid before the Geological Society in May I 87 by Messrs. Harkness and Hicks, whose paper on the Ancient Rocks of St. David's Promontory appears in the Geological Journal for November I871 (xxviii. 384). The Cambrian sediments here rest upon an older series of crystalline stratified rocks, described by the geological surveyors as syenite and greenstone, and having a north-west strike. Lying unconformably upon these, and with a north-east strike, we have the following series, in ascending order :- I, quartzose conglomerate, 6oft. 2, greenish flaggy sandstone, $460 f t$; 3, red flags or slaty beds, 5oft., containing Lingulella ferruginea, besides a larger species, Discinc, and Leperditic cambrensis; 4, purple and greenish sandstones, I,00oft. ; 5, yellowish gray sandstones, flags and shales, I 5 oft., with Plutonia, Conocoryphe, Microdiscus, Agnostus, Theca, and Protosponoia; 6, gray, purple and red flaggy sandstones, with most of the above genera, 1,500ft. ; 7 , gray tlaggy beds, I 5oft., with Paraloxides; 8 , true Menevian beds, richly fossiliferous, 50oft. The latter are the probable equivalent of the base of Barrande's Etage C, and at St. David's are conformably overlain by the Lingula flags, beneath which we have, including the Menevian, a conformable series of $3,37 \mathrm{oft}$. of uncrystalline sediments, fossiliferous nearly to the base, and holding a well-marked fauna distinct from anything hitherto known in Great Britain or elsewhere.

The Menevian beds are connected with the underlying strata by the presence of Lingulella ferruginea, Discina pileolus, and Obolella sagittatus, which extend through the whole series; and also by the genus Paradoxides, four species of which occur in the lower strata, from which the genus Olenus, which characterises the Lingula flags, seems to be absent. To a large tuberculated trilobite of a new genus found in these lowest rocks the name of Plutonia Sedgrvickii has been given. Hicks has proposed to uni'e the Menevian with the Harlech beds, and to make the summit of the former the dividing line between the Lower and Middle Cambrian, a suggestion which has been adopted by Lyell. (Proc. Brit. Assoc. for 1868, p. 68, and Lyell, Student's Mannal of Geology, 466-469.)

Both Phillips and Lyell give the name of Upper Cambrian to the Lingula flags and the Tremadoc slates, which together constitute the Middle Cambrian of Sedgwick, and concede the title of Lower Silurian to the Bala group or Upper Cambrian of Sedgwick. The same view is adopted by Linnarsson in Sweden, who places the line between Cambrian and Silurian at the base of the Llandeilo or the second fauna. It was by following these authorities that $I$, inadvertently, in my address to the American Association for the Advancement of Science in August r871, gave this horizon as the original division between Cambrian and Silurian. The reader of the first part of this paper will see with how much justice Sedgwick claims for the Cambrian the whole of the fossiliferous rocks of Wales beneath the base of the May Hill sandstone, including both the first and the second fauna. I cannot but agree with the late Henry Darwin Rogers, who, in 1856 , reserved the designation of "the true European Silurian" for the rocks above this horizon. (Keith Johnston's Physical Atlas, 2nd ed.)

(To be continued)

\section{ACOUSTICAL EXPERIMENTS*}

Showing that the Translation of a Vibrating Body CAUSES IT TO GIVE A WAVE-LENGTH DIFFERING FROM THAT PRODUCED BY THE SAME Vibrating BODY WHEN STATIUNARY

\section{The Apparatus}

FOUR tuning-forks mounted on resonant casss and giving the note $\mathrm{UT}^{3},=256$ complete vibrations per second, were $\left.0^{\prime}\right)$. tained. I will designate them as Nos. I, 2, 3, and 4 .

Nos. $I$ and 2 were brought into perfect unison by a process to be described.

No. I was placed before a lantern, an I just touching one of its prongs was a small ball ( 5 or $6^{\mathrm{mm}}$ diam.) of goot cork, su :pended by a silk fibre. The images of the fork and of the cork ball were projected on a screen.

No. 3 had one prong weighted with wax, so that it gave tws beats a second with No. I or 2 .

No. 4 had the ends of its prongs filed off, until it also gave two beats per second with $x$ or 2 ; thus No. 4 gave two vibra. tions a second more than No. r, while fork No. 3 gave two vibrations a second less than No. $r$.

\section{The Experiments}

In the experiments one to seven inclusive, fork No. I remains before the lantern, with the suspended cork ball just touching one of its prongs.

ExP. I. Fork No. 2, screwed on its case, was held in th: hand, at a distance of 30 to $60 \mathrm{ft}$. from No. $\mathrm{s}$, and sounded; the ball was projected fiom the prong of fork $I$, which vibrated in unison with 2 .

ExP. 2. I stationed myself $30 \mathrm{ft}$. distant from fork No. I, and fork No. 2 was screwed off its case and vibrated in one band, while the case was held in the other. I now walked rapidly toward fork $\mathrm{I}$, and after I was in regular motion I placed the fork on its case, and just before I ceased walking I took it off ; although, when I did so, I was only about a foot from fork $I$, yet the cork ball remained at rest against its prong.

ExP. 3. Again I walked toward I, as in Exp. 2, but I did not remove the fork from its case after it was placed on it. The ball remained at rest until the moment I suddenly stopped walking; at that instant the ball flew from the fork, while an assistant, whose ear was close to the case of fork $\mathbf{I}$, while his eye was directed to the screen, found that at the instant I stopped walking, the fork I sounded, while the ball jumped from its prong.

EXPS. 4 and 5. These experiments were exactly like Exps. 2 and 3 , except that I walked away from fork $I$ instead of approaching it. The results were the same as in Exps. 2 and 3 .

Ex.P. 6. Fork No. 3, giving 254 vibrations per second, was sounded as in Exp. I. It had no effect in moving the ball. I now screwed the fork off its case, and, standing about $30 \mathrm{ft}$. from fork I, with my arm I swung the case toward fork I, and while it was approaching it I placed fork No. 3 on the case; the proper velocity (from eight to nine feet per second) having been obtained, the ball was suddenly projected from fork $x$ On greatly increasing or decreasing the above velocity of the moving case, the vibrations of fork 3 produced no effect on fork $\mathbf{I}$.

Exp. 7. Fork No. 4, which gives two vibrations per second more than No. I, was substituted in Exp. 6, but was placed on its swinging case when this was receding from fork $I$. The effect of this motion and of varying velocities was the same as in Exp. 6.

ExP. 8. I placed fork 3 before the lantern, and swung fork I as in Exp. 7. The effects were the same as described in Exp. 7 .

ExP. 9. I now placed fork 4 before the lantern, and moved fork $I$ as in Exp. 6 . The effect on the ball was the same as in Exp. 6.

By these simple experiments I have shown the change of wave-length produced by the translation of the vibrating body, and have given an experimental proof of the important theorem which Doppler established in 184r. By analogy they clearly unfold that exquisite modern method of determining the motions

* By Alfred M. Mayer, Ph.D., Professor of Physics in the Stevens Institute of Technology, Hoboken, New Jersey (reprinted from the American Foumal of Science and Arts, vol, iil., April, 1872 ). 
of a heavenly body by variations in the refrangibility of the rays which it emits-motions often impossible even to detect by any other means. I therefore deem it proper that I should proceed to state the delicate conditions on which depend the perfection of experiments which so satisfactorily elucidate the nature of those grand and refined problems offered to spectral observation.

It is, first of all, essential that forks $\mathrm{I}$ and 2 should really be in unison. Two forks, sounded together, may give no perceptible beats, for they may constrain each other into a common forced oscillation, and thus both will give the same number of vibrations, yet may be removed from equality when separately vibrated. The process I have adopted is as follows: Three forks are taken which are supposed to give the same number of vibrations in a given time. They are supported on india-rubber tubing, and are thus insulated. One of the forks is now loaded so that it gives two or three beats in a second, with one of the other two that are to be brought into exact unison. The interval of time occupled by twenty or thirty of these beats is accurately determined by means of a chronograph (one of Casella's registering stop-watches does very well). The interval occupied by the same number of beats given with the second fork is now ascertained, and if it differs from that given by the first, the quicker vibrating fork is made to give the same number of beats as the slower by loading it with wax. When the forks have thus been carefully adjusted, I have had no difficulty in projecting the ball, in Exp. I, at a distance of sixty feet, and I believe that it could have been accomplished at a distance of Ioo feet. The ball of cork should be spherical, so that it will always just touch the fork, no matter how much it may rotate around its suspending thread, which latter should consist of only one or two fibres of unspun silk. The cork is rendered as smooth as possible and is then varnished; this is important, for the varnish gives a firm coating to the ball, without sensibly increasing its weight, and is especially useful in covering the minute asperities or elastic projections on its surface, which otherwise would act as "buffers" to the impacts of the fork and deaden its projectile effects.

The above-stated conditions having been obtained, no physicist will have any difficulty in repeating these experiments.

A machine has been devised by which a uniform motion of translation can be given to the forks, and with this I propose making a quantitative investigation of the phenomena, using an apparatus essentially the same in its action as the one here described.

We may substitute for the suspended cork-ball a light plane mirror, held between two stretched vertical fibres, while one of its edges touches the fork. The motions of a beam of light reflected from the mirror to a screen, indicate most beautifully the vibrations of the fork. This ingenious and most delicate device for detecting vibrations is due to Prof. O. N. Rood, of Columbia College, N.Y., who first used it in a public lecture, delivered in New York on the $28 \mathrm{th}$ of last December. We have, dowever, in our special work, found the image of the projected ball more convenient, and sufficiently delicate, for our experiments.

Quantitative relations in the experiments and analogical facts in the phenomena of light.

The $\mathrm{UT}_{3}$, No. I fork, makes 256 complete vibrations in one second, while fork No. 3 makes 254, giving for the respective wave-lengths of these vibrations 4.367 and $4 \cdot 401$ feet, which we will designate in order as $\lambda$ and $\lambda^{\prime}$. We will take 1,118 feet per second as the velocity of sound at $60^{\circ} \mathrm{F}$.

Now 256 vibrations in $1,118 \mathrm{ft}$. make $\lambda=4367 \mathrm{ft}$.

and $254 " \ldots 1,118-2 \lambda(=1,109 \cdot 266)$ give $\lambda=4,367 \mathrm{ft}$.

As the velocity of propagation of the vibrations and $\lambda$ are the same in both cases, it follows that $\left(n=\frac{\mathrm{V}}{\lambda}\right)$, the number of vibra-

tions in a second, reaching a distant point, is the same; and, therefore, 256 vibrations from a body at rest will produce the same effect on a distant surface, as 254 vibrations emanating from a body which moves toward that surface, with a velocity of $2 \lambda$, or of 8.734 feet per second ; and this is the velocity we gave the fork in Exps. 6 to 9.

We will no' examine the analogical phenomena in the case of light. Let fork No. $\mathrm{x}$, giving 256 vibrations a second, stand for 595 millions of millions vibrations a second, which we will take as the number of vibrations made by the ray $D_{1}$ of the spectrum. Then fork No. 3 will represent 590 millions of millions vibrations per second, which gave a wave-length 0000042 millimetre longer than that of $\mathrm{D}_{1}$, and nearly corresponds with an iron line situate ' 42 div. below $D_{1}$ on Angström's chart. We saw that fork No. 3 , giving 254 vibrations a second, had to move toward the ear with a velocity of $8.734 \mathrm{ft}$., to give the note produced by 256 vibrations per second, emanating from a fixed point; so a star sending forth the ray which vibrates 590 millions of millions times a second, will have to move toward the eye with a velocity of 28,470 miles per second to give the colour produced when ray $\mathrm{D}_{1}$ emanates from a stationary flame.

\section{SCIENTIFIC SERIALS}

Annalen der Chemie anu Phrmmacie, October 1871. Naumann has made a long series of experiments on the dissociation-tensions of ammonic carbonate, he finds that when it is volatilised it is entirely decomposed into ammonia and carbonic anhydride, and that for lower temperatures the dissociation-tensions of this body increase by increase of temperature precisely as the tensions of other substances. Leist has obtained three compounds of bismuth oxide with sulphuric acid, all of which are basic salts, he has not been able to form the normal salt except in combination with potassium. Faust has made a series of experiments on the derivatives of phthalic acid, he has obtained nitrophthalic, bromophthalic, and dechlorophthalic acids. Faust and Saame have made a careful examination of the chloro-compounds, both addition and substitution of naphthaline : this work has already been performed many years ago by Laurent; the authors have thought fit to commence a revision of the subject, but it is as yet far from complete. A very long paper by Schutzenberger follows " on the acetyl derivations of carbo-hydrates, mannite and its isomerides, and on certain vegetable products," this contains some interesting though complicated results. A translation of Dr. Mills' paper on the nitration of chloroform, and two other papers of less interest complete this number.

Annales de Chimie et de Physique, March 1872.-The greater portion of this number is occupied by the second part of .MM. Pierre and Puchot's researches on some of the bodies produced in fermentation. They give the results of a very detailed study of propylic alcohol, its haloid ethers, the formiate, acetate, propionate, butyrate, and valerate, and propylic aldehyde; butylic alcohol and the same series of ethers as above, and amylic alcohol with its butyrate and valerate. Besides these we have the detailed description of several other ethers, methyl valerate, and ethyl propionate and valerate, forming altogether a very complete and exhaustive monograph on these subjects. The author has also made some interesting observations on the "simultaneous distillation of water with certain alcohols insoluble therein." Thus a mixture of water and amylic alcohol, when submitted to distillation, boils at $96^{\circ}$, and a definite proportion of the two bodies is found in the distillate, at this temperature 2 parts of water and 3 of amylic alcohol invariably condense; should the water be in excess the whole of the amylic alcohol will pass over, the thermometer remaining at $96^{\circ}$. Butylic alcohol and water distil over at $90^{\circ} 5^{\circ}$ when a constant mixture of 5 parts of alcohol and I part of water condenses.-M. Bourgoin has electrolysed a solution of potassic phthalate, and finds that it splits up into water, carbonic oxide, and carbonic anbydride, an aqueous solution of phthalic acid does not appear to be decomposed by the electric current.

Tre Scottish Naturalist for April contains a number of short articles on various branches of Scottish Natural History. Among the more interesting may be mentioned especially a note by Dr. Buchanan White on the discovery in Braemar of a colony of Zygena exulans, a common moth in the Alpine districts of Southern Europe and in Scandinavia, but hitherto unknown in Britain. Dr. White considers it, like some of the characteristic plants of the district, a relic of the glacial epoch which once overspread Scotland; its characters are intermediate between the northern and southern forms. - Mr. George Sim contributes an important paper, comprising a list of the stalk-eyed Crustacea of the north-east coast of Scotland, with descriptions of new genera and species, and a plate. - The instalment of the catalogues of Insecta Scotica includes a continuation of the Lepidoptera by Dr. Buchanan White, and the commencement of the Coleoptera by Dr. D. Sharp. 